Canadian Journal of Civil Engineering

Canadian

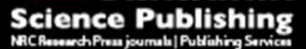

Revue canadienne de génie civil

\title{
Flexible pavement damage during spring thaw: a field study using the Falling Weight Deflectometer
}

\begin{tabular}{|c|c|}
\hline Journal: & Canadian Journal of Civil Engineering \\
\hline Manuscript ID & cjce-2017-0465.R1 \\
\hline Manuscript Type: & Article \\
\hline Date Submitted by the Author: & 15-Nov-2017 \\
\hline Complete List of Authors: & $\begin{array}{l}\text { Bilodeau, Jean-Pascal; Université de Laval, Department of civil engineering, } \\
\text { Laval University; } \\
\text { Doré, Guy; Université Laval, }\end{array}$ \\
\hline $\begin{array}{l}\text { Is the invited manuscript for } \\
\text { consideration in a Special } \\
\text { Issue? : }\end{array}$ & N/A \\
\hline Keyword: & $\begin{array}{l}\text { Spring thaw, Flexible pavement, Falling weight deflectometer, Pavement } \\
\text { damage, Fatigue }\end{array}$ \\
\hline
\end{tabular}

SCHOLARONE ${ }^{m}$

Manuscripts 


\section{Flexible pavement damage during spring thaw: a field study using the}

2 Falling Weight Deflectometer

3

4 Corresponding author

5 Jean-Pascal Bilodeau

6 Department of civil engineering

7 Laval University

81065 avenue de la Médecine

9 Québec, Canada

10 G1V 0A6

11 418-656-2131 \#7242

12 jean-pascal.bilodeau@gci.ulaval.ca

Spring thaw creates critical performance conditions for pavement networks. The increase of water content in the pavement environment is significant during spring thaw. Combined with poor drainage conditions, materials condition variations are triggering factors that accentuate the effect of heavy vehicle loading on pavement response and damage. Two experimental pavement sections were monitored in 2014 and 2015 for temperature and deflections. the section with the lowest structural capacity was found to be more sensitive to thaw weakening. Fatigue damage calculated for this section was found to be $31 \%$ higher than the section with the highest structural capacity. Moreover, it was shown that a load reduction in the range of 20 $\%$ can decrease the total yearly damage by about 7 to $10 \%$ for the considered test sections. In general, fatigue damage was found to increase from spring onset to the warmest conditions of the yearly cycle, in July.

37

38 Keywords: Spring thaw, flexible pavements, falling weight deflectometer, pavement damage 


\section{Flexible pavement damage during spring thaw: a field study using the 41 Falling Weight Deflectometer}

\section{Introduction and background}

46 In areas subjected to seasonal freeze, the structural capacity of flexible pavements significantly

47 varies throughout the yearly cycle. This variation is associated with, among other things, the

48 effect of freezing and low temperatures on the stiffness of soils, unbound granular materials and

49 asphalt concrete, and with the thaw weakening mechanisms. As a matter of fact, it is reported

50 in the literature that a significant part of yearly pavement damage occurs during the spring thaw

51 period (Janoo and Shoop 2004; Barksdale 1991; Saint-Laurent 2003). The weakening of flexible

52 pavement during spring thaw can be divided into two distinct periods (Doré and Zubeck 2009;

53 Konrad and Roy 2000; Doré 1997). In early spring, the thaw front penetrates the pavement from

54 the surface, typically with a deeper thaw penetration underneath the center of the pavement.

55 The melting of snow in pavement environments, as well as frequent liquid precipitation, will

56 typically cause an important increase of the degree of saturation within the granular layers

57 underneath the asphalt concrete layer due to poor drainage conditions in the thawed zone

58 (Côté 1997; ). This increase in the degree of saturation combined with poorly drained layers

59 causes a decrease of material stiffness and resistance to permanent deformation (Bilodeau

60 2009; Lekarp et al. 2000a; Lekarp et al. 2000b; Theyse 2002; Bilodeau and Doré 2012; Suarez et

61 al. 2010; Doucet and Doré 2004; Richter 2006; Ekblad 2007; Uthus 2007). Positive water 
62 pressures were also reported during early spring periods (Thom and Brown 1987), leading to a 63 decrease in effective stress.

64

65 During the period referred to as late spring, the upper thaw front reaches subgrade soils that

66 are typically more thaw sensitive, while the lower thaw front slowly migrates upward (Konrad

67 and Roy 2000). The melting of ice lenses that formed in the subgrade soil during winter

68 combined with water from melting snow and ice and frequent rain events in spring contribute

69 to high degree of saturation in the soils. The vulnerable soil state and the consolidation process

70 in thawing soils are the main factors contributing to the decrease of the pavement bearing

71 capacity and the increase of its sensitivity to damage accumulation (Doré 2004). It is reported in

72 the literature that weakening in flexible pavements can be associated with the rate of thawing,

73 the rate of consolidation, the thickness of the subgrade soil affected by frost action and the

74 magnitude of frost heave (Doré 2004; Andersland and Ladanyi 2004; Nixon and Morgenstern

75 1971). Because of their typically higher segregation potential, water sensitivity and lower

76 drainage capacity, fine grained subgrade soils typically show higher bearing capacity loss during

77 springtime. A $50 \%$ loss is expected in fide-grained soils, while $10-35 \%$ loss is expected in clean

78 sand and gravels to silty-clayey gravel-sands (Doré and Zubeck 2009). Pavement damage, such

79 as fatigue and alligator cracking, permanent deformation, and roughness deterioration, are

80 generally found to significantly increase during spring thaw (Doré and Savard 1998).

82 The effect of variation in the degree of saturation of flexible pavement performance, has been

83 investigated by Saevarsdottir and Erlingsson (2013). Using accelerated pavement testing of an

84 experimental pavement structure, for conditions reported as moist and wet (silty sand subgrade 
85 water content of 8 and $16 \%$, respectively), the authors found a significant increase in tensile

86 strain at the bottom of the asphalt concrete layer (between $20-45 \%$, for two different flexible

87 pavement structures). Moreover, in a recent FWD study on an experimental site in Sweden,

88 Salour and Erlingsson (2013) showed that the stiffness decrease during spring thaw was about

$8948 \%$ for pavement granular layers and $60 \%$ for a sandy silt subgrade. During this study, the

90 thaw-weakening period lasted about three weeks, and the recovery period lasted more than

91 two months. Deflection indices - such as Maximum Deflection (Dmax), the Surface Curvature

92 Index $(\mathrm{SCl})$, the Base Deflection index (BDI) and the Base Curvature Index $(\mathrm{BCl})$-all reached a

93 yearly maximum during the spring thaw. All indices increased by approximately $30 \%$ during thaw

94 weakening (relative to recovered values). The dissipated energy measured in the hysteresis loop

95 of FWD deflection sensors also confirmed that a significant amount of damage occurs in the

96 pavement system during spring thaw. In a weakened state, the measured dissipated energy can

97 be approximately 3.6 times larger than the dissipated energy measured in recovered state.

98 Finally, the back calculated moduli for a given layer during spring thaw were highly correlated

99 with the water content in the layer.

100

101

102

103

105 Due to bearing capacity loss during the spring period, many transportation agencies enforce

106 spring load restrictions (SLR) for commercial vehicles in order to protect and maintain the 
107 pavement network. This is the case in Canada, in some US states, and in some European

108 countries. According to Ovik et. al. (2000), SLR are typically enforced at the end of February or 109 beginning of March, and remain in effect until April or May (an eight-week period is standard).

110 According to Doré and Zubeck (2009), regional and local networks are most sensitive to thaw

111 weakening and many agencies use these regulations primarily to protect the secondary

112 network. These regulations are likely to have an important impact on pavement life. Indeed,

113 load reductions of $20-50 \%$ during spring thaw may extend pavement life by $62-95 \%$. According

114 to Saint-Laurent (2003), actual SLR practices in Quebec province (Canada) help reduce the truck

115 factor of heavy vehicle by about $22 \%$, but cause an increase of about $7 \%$ in number of trucks

116 using the network. Load-associated damage during spring thaw makes up $18-72 \%$ of the total

117 yearly damage. According to Saarenteko and Aho (2005) weight restrictions that are

118 implemented seven days too late can decrease pavement service life by $4-8 \%$. These

119 percentages can increase to $5-12 \%$ if winter loading premium loads are removed seven days too

120 late. The expected savings of an SLR program was documented by C-SHRP (2000) for

121 administrations around the world. The study took various factors (such as climate and traffic)

122 into account and found that the average savings associated with SLR is approximately $79 \%$

123 (when an economic analysis is performed for a severe winter with and without SLR).

125 As shown Table 1, spring load restriction practices vary across Canada (Bullock et al. 2006; C-

126 SHRP 2000). According to Doré and Zubeck (2009), there are as many criteria and regulations as

127 there are northern transportation agencies. MacLeod et al. (2002) and Saarenteko and Aho

128 (2005) state that these regulations change with the need, size, and duration of the restriction

129 period. The criteria used to decide when to begin SLR is usually based on direct or indirect 
130 methods. Ovik et al. (2000) summarized the criteria used to decide when SLR procedures should

131 be in effect. The methods include:

132 - $\quad$ Fixed date;

133 - Engineering judgement;

$134 \quad-\quad$ Pavement history;

135 - Pavement design;

136 - Visual observations (such as water seeping from the pavement);

137 - Daily air and pavement temperature measurements;

138 - Frost depth measurements (drive rods, frost tubes, or other sensors);

139 - Deflection tests.

140 As stated by Ovik et al. (2000), deflection testing is less practical than other techniques, due to

141 the relatively rapid changes in conditions during early spring thaw, combined with the large

142 territories and distances that need to be covered. In can be noted that, from the work of Ovik's

143 (2000) on US states that enforce SLR policies using engineering judgement, experience and

144 analytical approaches, qualitative approaches are more used in general practice than

145 quantitative approaches.

146

147 Considerable research efforts have been conducted in the past few decades on thaw weakening.

148 However, research on the complex interaction between heavy loads and pavement response

149 during spring thaw is still necessary due to the important impact of SLR on the industry, the

150 need to preserve the pavement networks. The research project presented in this paper is part of 
151 a larger research initiative on the implementation of automated road weather stations in

152 Quebec for continuous monitoring of pavement temperatures. As part of the project, two

153 representative experimental pavement sections, , were intensively monitored during spring

154 thaw. The objective of this paper is to quantify the amount of theoretical fatigue damage that

155 occurs in typical pavement structures built in Quebec province using structural response

156 measurements obtained from falling weight deflectometer tests.

158 Table 1. Criteria for imposing and lifting spring load restrictions across Canada (after Bullock et 159 al. 2006)

\begin{tabular}{|c|c|c|}
\hline Province & SLR imposition method & SLR lifting method \\
\hline Quebec & $\begin{array}{l}\text { Frost tubes and automated } \\
\text { road weather stations ( } 300 \\
\mathrm{~mm} \text { thaw depth) }\end{array}$ & $\begin{array}{l}5 \text { weeks after thaw depth } \\
\text { reaches } 900 \mathrm{~mm}\end{array}$ \\
\hline Ontario & $\begin{array}{l}\text { Temperatures and road } \\
\text { condition }\end{array}$ & Fixed dates \\
\hline Manitoba & Thawing index & Fixed dates \\
\hline Saskatchewan & $\begin{array}{l}\text { Thermistors, climate and } \\
\text { road conditions }\end{array}$ & $\begin{array}{l}\text { Road inspection or maximum } \\
\text { length of } 6 \text { weeks }\end{array}$ \\
\hline Alberta & $\begin{array}{l}\text { Frost tubes ( } 300 \mathrm{~mm} \text { thaw } \\
\text { depth), climatic conditions }\end{array}$ & FWD and frost tubes \\
\hline British Columbia & $\begin{array}{l}\text { Frost tubes, engineering } \\
\text { judgment, climate historical } \\
\text { data }\end{array}$ & Benkelman beam survey \\
\hline New Brunswick & Temperatures & $\begin{array}{l}\text { FWD, Benkelman beam and } \\
\text { road conditions }\end{array}$ \\
\hline Nova Scotia & Climate and road conditions & $\begin{array}{l}\text { Dynaflect and road } \\
\text { conditions }\end{array}$ \\
\hline Prince Edward Island & $\begin{array}{l}\text { Frost tubes and Benkelman } \\
\text { beam survey }\end{array}$ & $\begin{array}{l}\text { Frost tubes, Benkelman } \\
\text { beam survey and climate }\end{array}$ \\
\hline Yukon & Thermistors & Thermistors \\
\hline Northern Territories & Pavement inspection & $\begin{array}{l}\text { Benkelman beam and } \\
\text { pavement inspection }\end{array}$ \\
\hline
\end{tabular}

\section{Experimental site and methods}


164 Two experimental pavement structures located at the Laval University experimental site of Forêt

165 Montmorency were intensively monitored for two years (2014 and 2015). Figure 1 presents the

166 average daily temperature for the two years of monitoring. The air freezing index $F l_{a}$ values

167 were 1889 and $1938^{\circ} \mathrm{C}^{*} \mathrm{~d}$ for 2015 and 2014, respectively. The experimental site is located near

168 kilometer 103 along national highway 175, on local road 33. The two experimental pavement

169 structures are built over a silty sand subgrade (SM) with $20 \%$ of fine particles and except for the

170 asphalt concrete thickness, they are identical. As illustrated in figure 2, the pavement layered

171 systems tested consist of $450 \mathrm{~mm}$ of granular subbase (SB), $200 \mathrm{~mm}$ of granular base (B) and

$172100 \mathrm{~mm}$ or $200 \mathrm{~mm}$ of asphalt concrete (AC). It should be noted that the base and subbase

173 materials at the test site are poorly differentiated and very similar.

a)

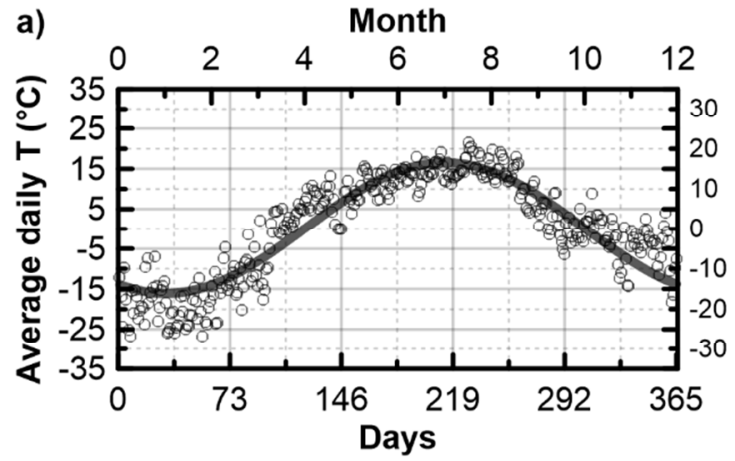

b)

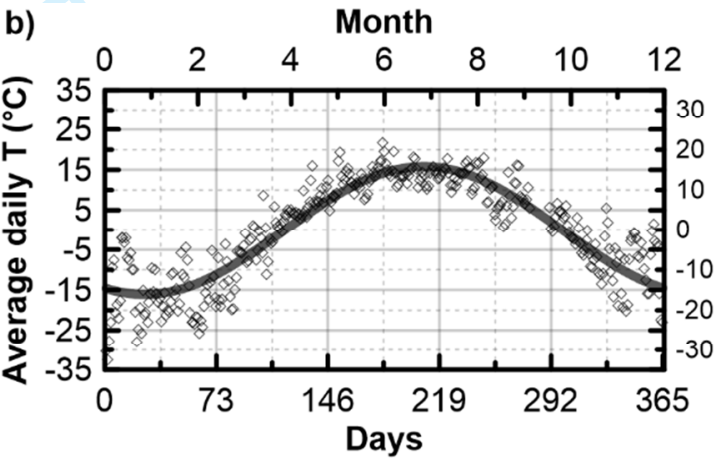

176 Figure 1. Average daily temperatures for 2014 (a) and 2015 (b) at the Forêt Montmorency experimental 177 site 
$200 \mathrm{~mm}$ AC section

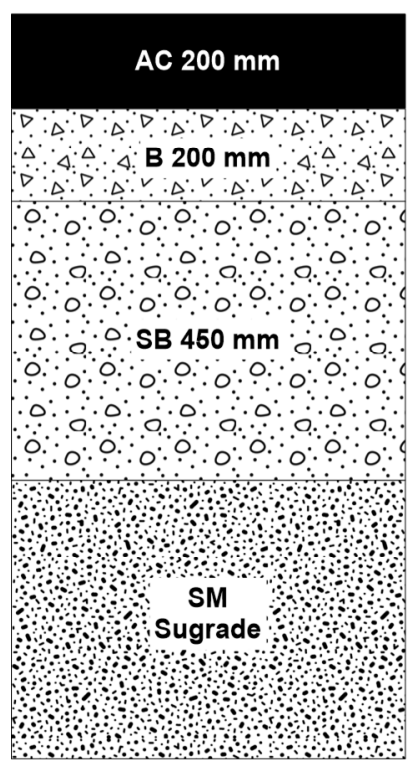

$100 \mathrm{~mm}$ AC section

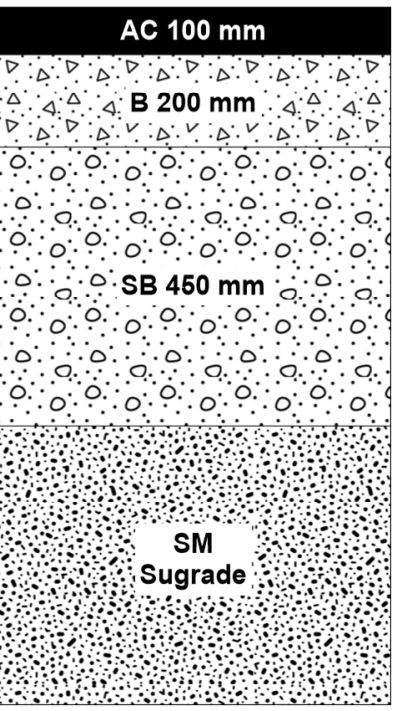

Figure 2. Tested experimental sections

For the $100 \mathrm{~mm} \mathrm{AC} \mathrm{section,} \mathrm{the} \mathrm{AC} \mathrm{layer} \mathrm{consists} \mathrm{of} \mathrm{hot-mix} \mathrm{asphalt} \mathrm{with} \mathrm{a} \mathrm{maximum} \mathrm{aggregate}$ size of $10 \mathrm{~mm}$ (ESG-10). For the $200 \mathrm{~mm} \mathrm{AC} \mathrm{section,} \mathrm{two} \mathrm{different} \mathrm{hot-mix} \mathrm{asphalts} \mathrm{were} \mathrm{used.}$

The top layer consists of an ESG-10 mix, while the bottom layer consists of a hot-mix asphalt with a maximum aggregate size of $20 \mathrm{~mm}$ (GB-20). Some of the volumetric properties of the AC damage will be quantified in this study Therefore, Table 2 also introduces the KF1 parameter, which is obtained from the mix properties and which is used in the Asphalt Institute's empirical transfer function for fatigue cracking (Asphalt Institute 1991; Bilodeau et al. 2017). This function is defined by

[1] $\quad \mathrm{N}_{\mathrm{F}}=0.001135 \times \mathrm{K}_{\mathrm{F} 1}|\varepsilon|^{(-3,291)} \times\left|\mathrm{E}^{*}\right|^{(-0,854)}$ 
$194 \quad[2] \quad K_{F 1}=10^{4,84 *\left(\frac{V_{b e}}{V_{v}+V_{b e}}-0,69\right)}$

195

196 in which $N_{F}$ is the allowable number of load repetitions prior fatigue cracking failure, $\varepsilon$ is the

197 tensile strain developing at the bottom of the asphalt concrete layer and $\left|E^{*}\right|$ is the dynamic

198 modulus. Both mixes have been characterized using complex modulus testing and the results

199 have been used to quantify the parameters of the Witczak model. This model is used in

200 Quebec's standards (Doucet and Auger, 2012) and is defined by

201

[3] $\log \left|E^{*}\right|=\delta+\frac{\alpha}{1+\boldsymbol{e}^{\left(\boldsymbol{\beta}+\gamma \log f_{r}\right)}}$

202

203

[4] $f_{r}=a_{T} * f$

204

205

[5] $\quad \log a_{T}=a_{1} *\left(T-T_{r}\right)+a_{2} *\left(T-T_{r}\right)^{2}$

206

207 Table 3 presents the results of the complex modulus characterization. Complex modulus tests

208 have been performed in order to define the range of dynamic modulus values to be expected

209 for the backcalculation process.

Table 2. Asphalt concrete mix characteristics

\begin{tabular}{ccc}
\hline Parameters & $\begin{array}{c}\text { AC } 100 \mathrm{~mm} \\
\text { (ESG 10) }\end{array}$ & $\begin{array}{c}\text { AC 200 } \mathrm{mm} \\
\text { (GB-20) }\end{array}$ \\
\hline $\mathrm{V}_{\mathrm{be}}(\%)$ & 5.3 & 4.5 \\
$\mathrm{~V}_{\mathrm{v}}(\%)$ & 5.2 & 5.8 \\
$\mathrm{~K}_{\mathrm{F} 1}$ & 0.127 & 0.060 \\
\hline
\end{tabular}


Table 3. Witczak model parameters for the asphalt concrete

\begin{tabular}{cccc}
\hline & ESG-10 & ESG-10 & GB-20 \\
& $(100 \mathrm{~mm} \mathrm{AC})$ & $(200 \mathrm{~mm} \mathrm{AC})$ & $(200 \mathrm{~mm} \mathrm{AC})$ \\
\hline$\delta$ & 0.261 & 0.675 & -0.543 \\
$\alpha$ & 4.196 & 3.811 & 4.983 \\
$\beta$ & -1.404 & -1.362 & -1.934 \\
$\gamma$ & -0.402 & -0.422 & -0.395 \\
$a_{1}$ & -0.145 & -0.147 & -0.144 \\
$a_{2}$ & $5.01 * 10^{-4}$ & $6.03 * 10^{-4}$ & $3.61^{*} 10^{-4}$ \\
\hline
\end{tabular}

217 Falling weight deflectometer (FWD) tests have been carried out periodically over the two years

218 of monitoring, with more intensive measurements during spring thaw. In 2014, 11 deflection

219 tests were carried out between April $13^{\text {th }}$ and September $24^{\text {th }}$. In 2015 , a total of 10 deflection

220 tests were performed between April $17^{\text {th }}$ and September $22^{\text {nd }}$. Table 4 summarizes the dates at

221 which the tests have been done along with the corresponding asphalt concrete temperature.

222 FWD deflection basins have been used to backcalculate the modulus of each layer. For the AC

223 layer, in addition to backcalculation, the dynamic modulus has also been determined using

224 Witczak model using the temperature measured manually within the asphalt concrete layer and

225 the load frequency $f$ determined using the following relationship:

$227 \quad[6] \quad \mathrm{f}=\frac{1}{2 \pi \mathrm{t}}$

229 in which $t$ is the duration of the half-sine loading pulse. 
Table 4. Dates of testing in 2014 and 2015 and asphalt concrete temperature

\begin{tabular}{lclc}
\hline 2014 & \multicolumn{3}{l}{ 2015 } \\
Date & $T_{\mathrm{AC}}\left({ }^{\circ} \mathrm{C}\right)$ & Date & $T_{\mathrm{AC}}\left({ }^{\circ} \mathrm{C}\right)$ \\
\hline April 11th & 12.3 & April 13th & 15.8 \\
April 17th & 4.3 & April 16th & 12.4 \\
April 24th & 3 & April 20th & 9.6 \\
April 30th & 7 & April 22nd & 8.9 \\
May 5th & 7.5 & April 28th & 11.2 \\
May 12th & 9.8 & May 29th & 26.6 \\
May 20th & 15.5 & June 3rd & 19.6 \\
Mai 26th & 17 & June 11th & 18 \\
June 9th & 25.3 & August 24th & 28.4 \\
August 20th & 22.9 & September 24th & 18.7 \\
September 22nd & 18 & - & - \\
\hline
\end{tabular}

The deflection basins have been collected with the following geophone distances: $0,200,300$,

$233450,600,900,1200,1500$ and $1800 \mathrm{~mm}$. Loads of 32, 40, 53 and $71 \mathrm{kN}$ were used on a $300 \mathrm{~mm}$

234 diameter plate, for surface contact stresses $\sigma_{0}$ of $453,566,750$ and $1004 \mathrm{kPa}$. The $300 \mathrm{~mm}$ plate

235 diameter was selected because it is the standard plate, which provides equivalent surface

236 contact similar to the one obtained by standard dual wheel. Figure 3 presents examples of

237 deflection basins collected at $40 \mathrm{kN}$ for the 100 and $200 \mathrm{~mm} \mathrm{AC}$ sections in 2014 and 2015.

238 Variations in the deflection basins can be observed between the spring and summer period. The

239 pavement behaviour is influenced by spring thaw weakening, but also by AC temperature. In

240 order to quantify the pavement structural capacity, backcalculation of the layers modulus was

241 performed. The backcalculation software ELMOD was used to fit the measured deflection at a

242 distance $i$ from load center $\mathrm{d}_{\mathrm{i}}^{\mathrm{m}}$ with the calculated deflection $\mathrm{d}_{\mathrm{i}}^{\mathrm{c}}$ using iterative layer modulus

243 variations to minimize the residual mean square error (RMSE). This backcalculation optimization

$244 \quad$ was performed using 
246 [7] $\left|\varepsilon_{i}\right|=\left|\frac{d_{i}^{c}-d_{i}^{m}}{d_{i}^{m}}\right|=\left|1-\frac{d_{i}^{c}}{d_{i}^{m}}\right|$

247

248 [8] $\operatorname{RMSE}(\%)=\sqrt{\frac{1}{n} \sum\left(100 * \varepsilon_{i}\right)^{2}}$

249

250 in which $\varepsilon_{i}$ is the relative difference between $d_{i}^{m}$ and $d_{i}^{c}$ for a given geophone distance $i$ from

251 the load center and $n$ is the number of geophones. The deflection basins have not been

252 corrected for temperature in order to determine the appropriate modulus for each layer for

253 further analysis of pavement response using multilayer elastic theory. Moreover, no

254 temperature correction has been used since actual layer modulus were needed to assess the

255 allowable number of load repetitions with equation 1, and corresponding pavement damage. 

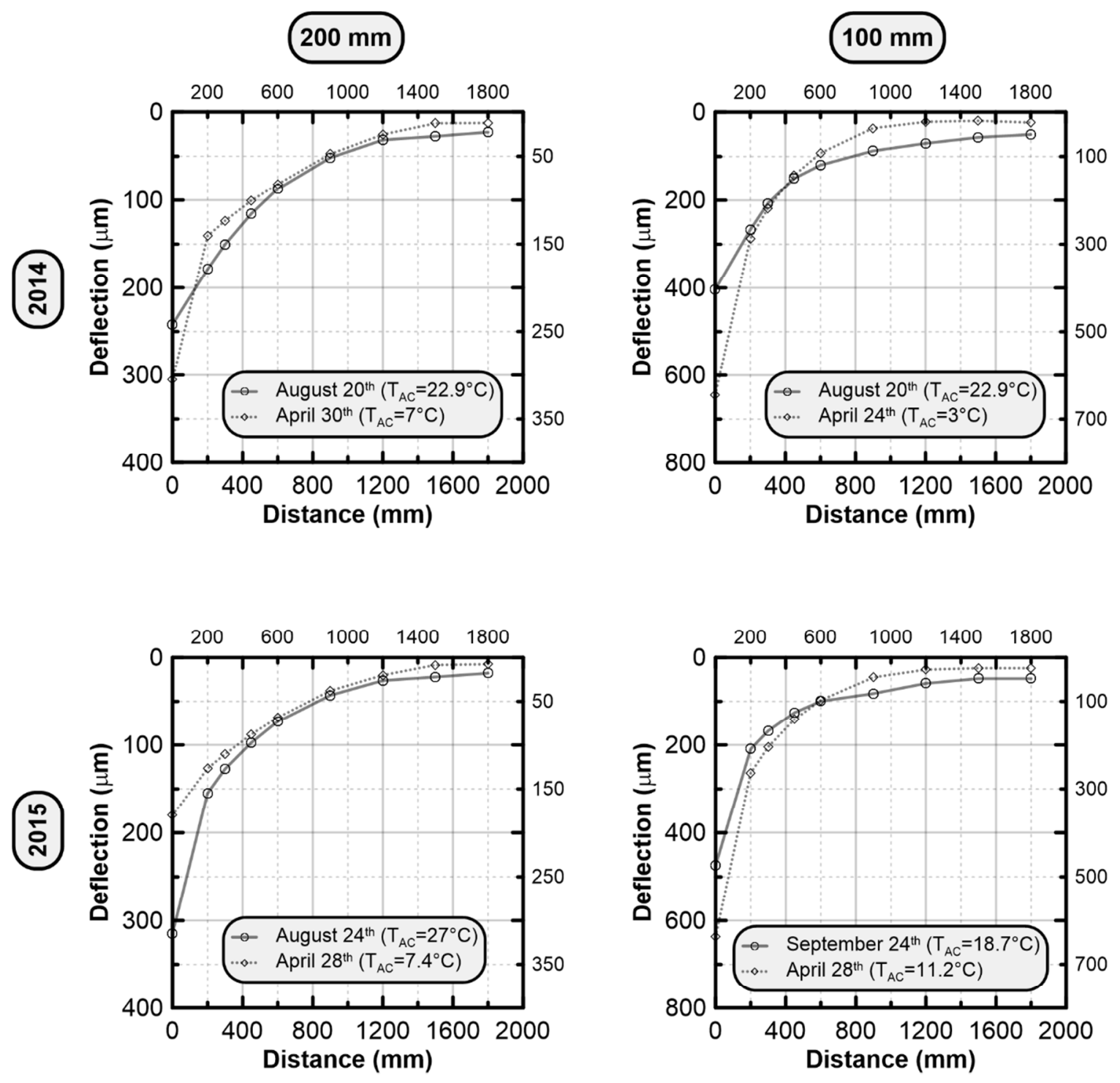

Figure 3. Examples of deflection basins measured in 2014 and 2015 for the 200 and $100 \mathrm{~mm}$ AC test sections

\section{Experimental results and discussion}

263 Figure 4 presents the thaw penetration in the 100 and $200 \mathrm{~mm} \mathrm{AC} \mathrm{sections} \mathrm{for} 2014$ and 2015.

264 The frost penetration was larger in 2014, resulting in a larger thaw depth, as shown in the figure.

265 Figure 5 presents the results of the backcalculated elastic modulus of the pavement layers 
266 during the monitoring period of 2014 and 2015. It can be observed that, as the thaw front 267 progresses downward within the pavement structure (Figure 4), the elastic modulus of the 268 layers changes significantly. It should be noted that the results presented are punctual 269 measurements during the monitored period and that they may be influenced by specific factors, 270 such as temperature, at the time of testing. For example, for the results presented, the 271 increasing air temperatures induces warming of the asphalt concrete layer, which can be 272 noticed from the spring to summer period. The highest dynamic modulus for the asphalt 273 concrete layer recorded during the monitoring period of April to November of each year, 274 reached $16000 \mathrm{MPa}$. The dynamic modulus decreased to $2700 \mathrm{MPa}$ for the summer (100 mm AC 275 section). The important decrease of the stiffness of the unbound layers during the thawing of 276 the experimental pavement sections is noticed approximately from mid-April to May. The 277 decreased elastic modulus are about 30-40, 100-200 and 100-250 MPa for the subgrade, 278 subbase and base layer, respectively, depending on the year and pavement section considered.

279 For each year and experimental section, following the moment when the unbound layers and 280 soil elastic modulus were the lowest (thaw depth of approximately $900-1000 \mathrm{~mm}$ ), the recovery 281 period is noticeable with respect to the experimental results collected. For the subgrade soil, 282 subbase and base, the recovered elastic modulus is in the range of $60-120,300-450$ and $300-450$ $283 \mathrm{MPa}$, respectively. The increase of the unbound granular layers elastic modulus during summer 284 is also partly attributed to the stress dependence of these materials. The progressive decrease 285 of the dynamic modulus of the asphalt concrete layer increases the stress transmitted to the 286 granular layers increasing thus their modulus. 

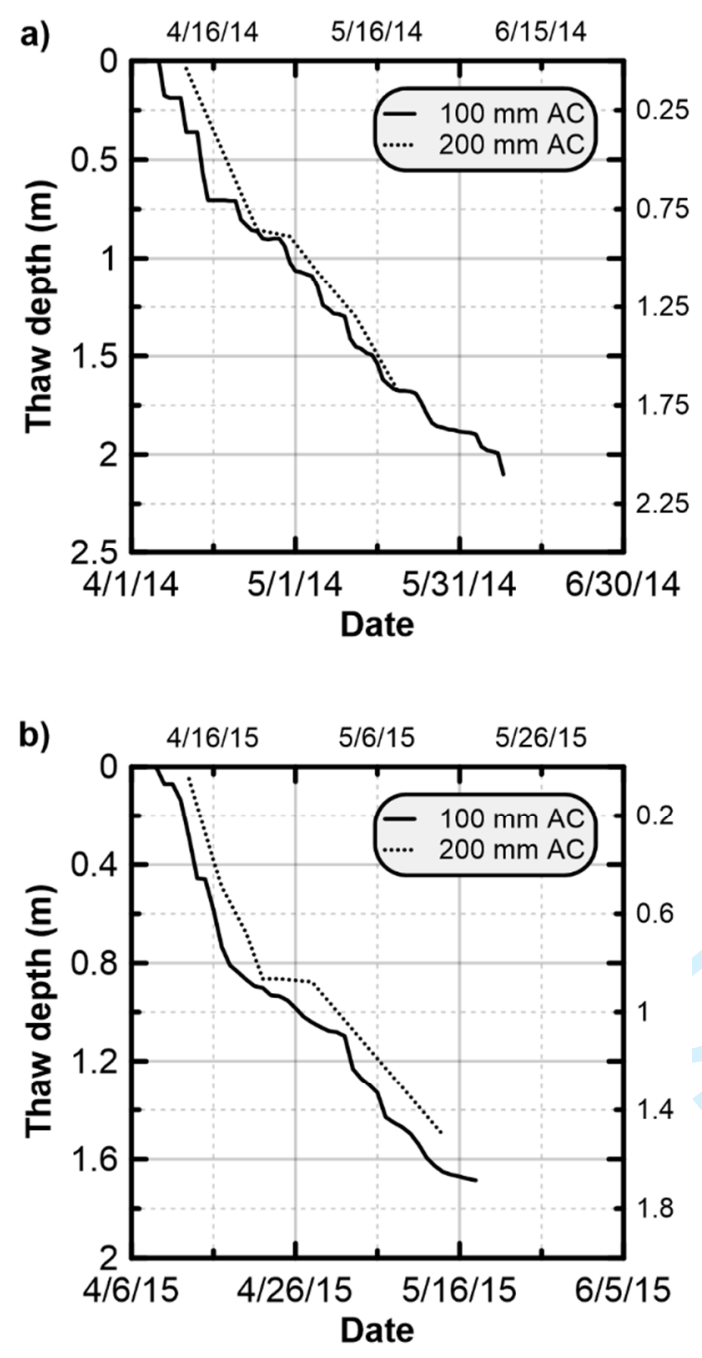

290

Figure 4. Thaw penetration in 2014 and 2015 for the two experimental test sections

291

292

293 

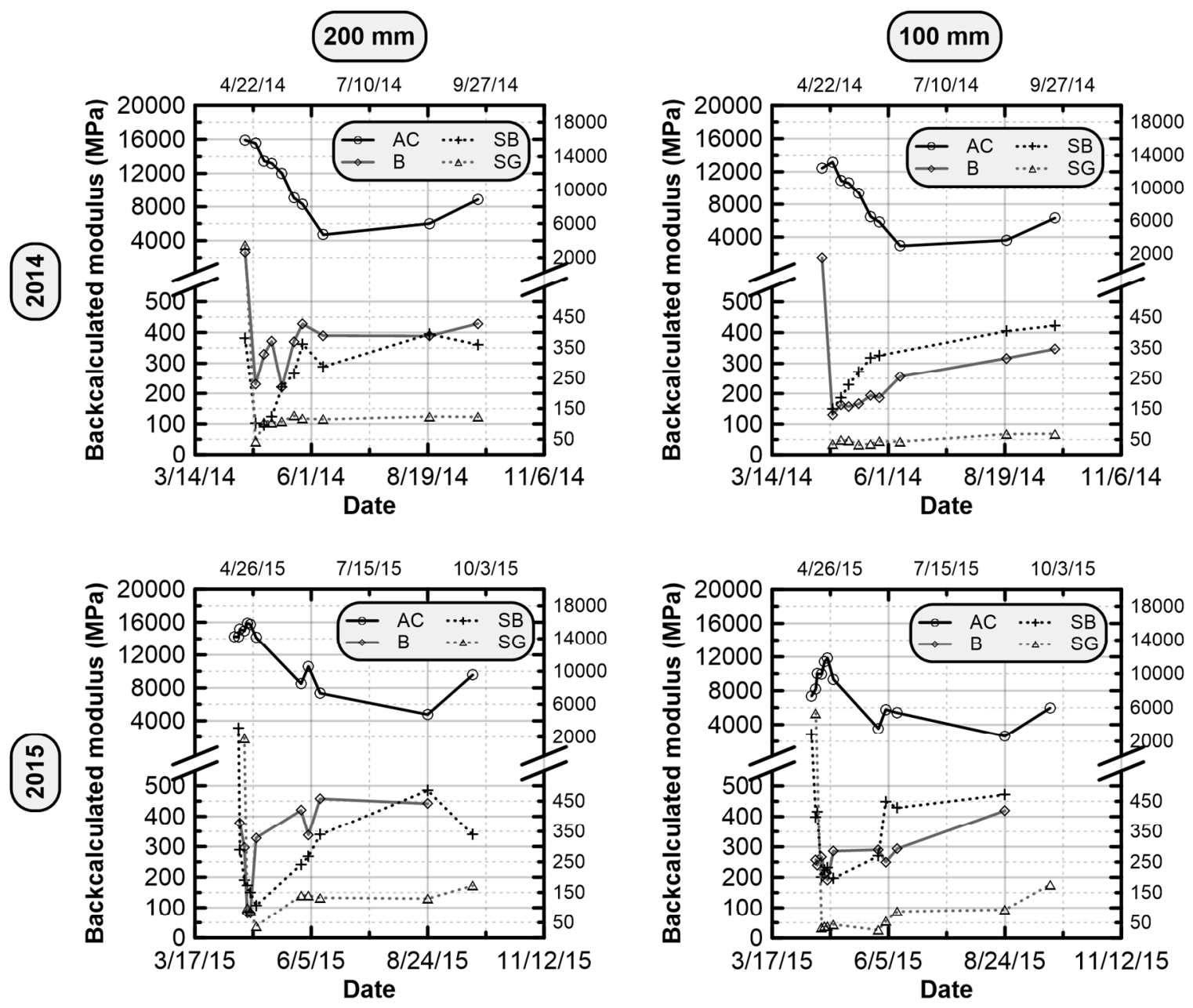

Figure 5. Backcalculated layers elastic modulus in 2014 and 2015 for the 200 and $100 \mathrm{~mm} \mathrm{AC} \mathrm{test}$ sections

A fatigue damage analysis was performed using the FWD data collected over the two years of experimental pavement response monitoring. This analysis is based on surface deflections obtained with the FWD tests. The deflection basins measured were used to backcalculate layers

301 modulus, which were used to determine critical tensile strain at the bottom of the asphalt

302 concrete using multilayer linear elastic calculations. From the tensile strain, the allowable number of load repetitions prior fatigue failure was determined using the empirical transfer 
304 function introduced in equation 1 . Finally, the damage $D$ was calculated using the Miner's

305 hypothesis of linear damage accumulation expressed by equation 9:

$$
D=\frac{n}{N_{a d m}}
$$

309 in which $n$ is the actual number of load repetitions and $N_{\text {adm }}$ is the allowable number of load 310 repetitions, calculated with Equation 1 for fatigue cracking $\left(N_{\mathrm{F}}\right)$. In order to quantify $N_{\mathrm{F}}$ using the 311 empirical transfer function and then the damage, the tensile strain $\varepsilon$ at the bottom of the 312 asphalt concrete layer occurring under the FWD loading conditions of 40, 36 and $32 \mathrm{kN}$, was 313 calculated using the software WinJULEA. This software uses the multilayer elastic calculation 314 proposed by Burmister (1942). The backcalculated layers modulus (example in Figure 5), as 315 determined with MODCOMP, for each load and testing date were used in WinJulea as elastic 316 modulus. The layer thicknesses given in Figure 2 were used as inputs in the multilayer elastic 317 software. A surface contact of $70686 \mathrm{~mm}^{2}$ was used for the circular loading plate (diameter of $318300 \mathrm{~mm}$ ), and Poisson ratio of 0.35 were used for each layer, with the exception of the subgrade 319 where a value of 0.45 was used. For the winter, typical elastic modulus values of 10000,1000 , 320800 and $500 \mathrm{MPa}$ were used for the AC, base, subbase and subgrade, respectively (Doré and 321 Zubeck 2009). Since the actual number of load repetitions $n$ is not a known parameter for this 322 theoretical analysis, the damage $D_{\mathrm{i}}$ experienced for 1 load repetition at measurement $i$ is used 323 and is defined as 
$325 \quad[10] \quad D_{i}=\frac{1}{N_{a d m-i}}$

327 in which $n$ was set to 1 . The value of $D_{\mathrm{i}}$ was calculated for each date where measurements were

328 taken. The damage was normalized $\left(D_{\text {norm }}\right)$ with respect to the damage measured in summer

329 conditions with

[11] $\quad D_{\text {norm }}=\frac{\mathrm{D}_{\mathrm{i}}}{\mathrm{D}_{\text {summer }}}$

333 where $D_{\text {summer }}$ is the damage experienced in summer. The $D_{\text {norm }}$ value allows a direct

334 quantification of the effect of the variation of the environmental conditions in terms of

335 pavement damage, which is inferred from fatigue empirical transfer function. Therefore, as the

336 focus of this study is to document the effect of environmental condition on pavement response

337 and performance, with focus on spring thaw, this data representation allows assessing the

338 relative damage accumulation changes that occur from season to season. For each load

339 considered, Figure 6 presents the AC thickness, the year and the $D_{\text {norm }}$ with respect to time. For

340 example, a $D_{\text {norm }}$ value of 2 in Figure 6 would mean that a load applied at a specific date and for

341 specific conditions would cause twice the damage induced by the same load applied in summer

342 conditions. Considering the SLR policies used in Quebec, the SLR start and end dates for 2014

343 and 2015 are presented in Table 5. As observed in Figure 6, the $D_{\text {norm }}$ value as a function of time

344 shows that almost no damage occurs during the winter, but there is a rapid increase of damage

345 when spring thaw begins until the pavement is at its warmest conditions around early July. The 
347 effect of SLR.
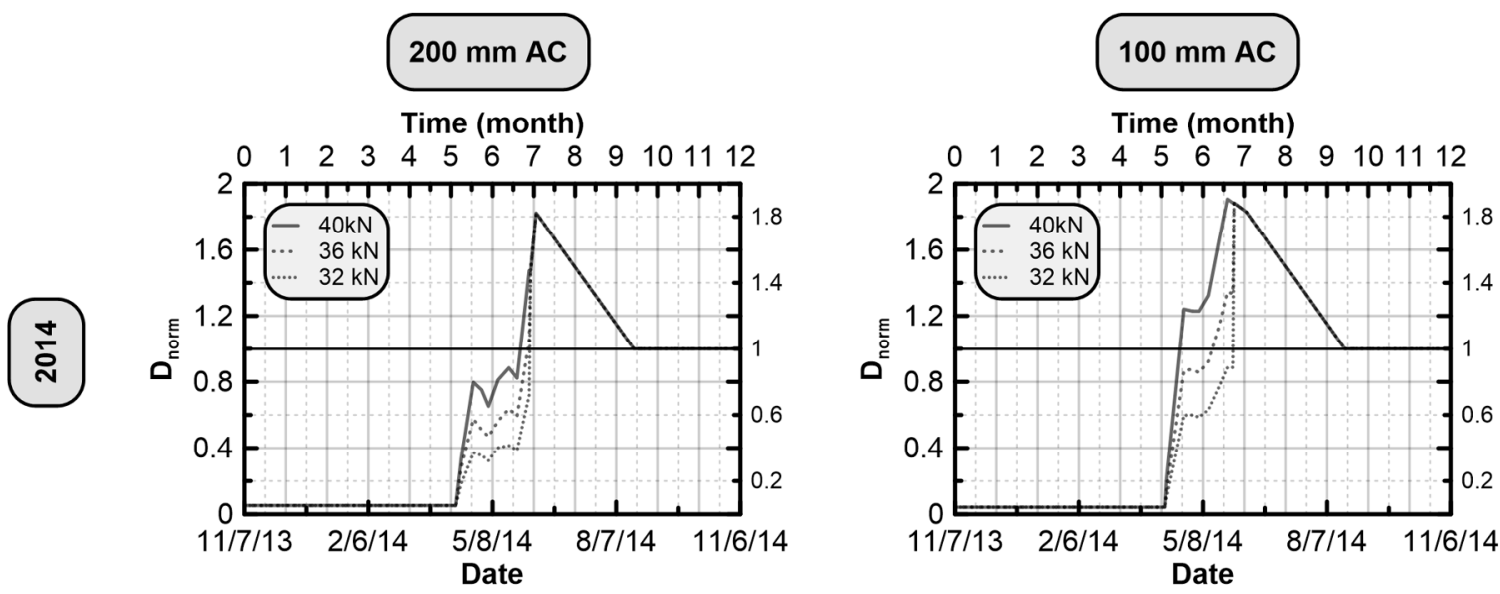

Time (month)

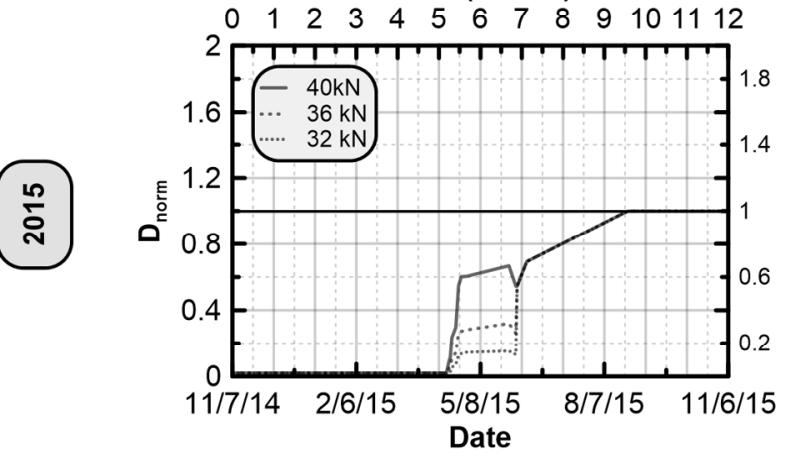

Time (month)

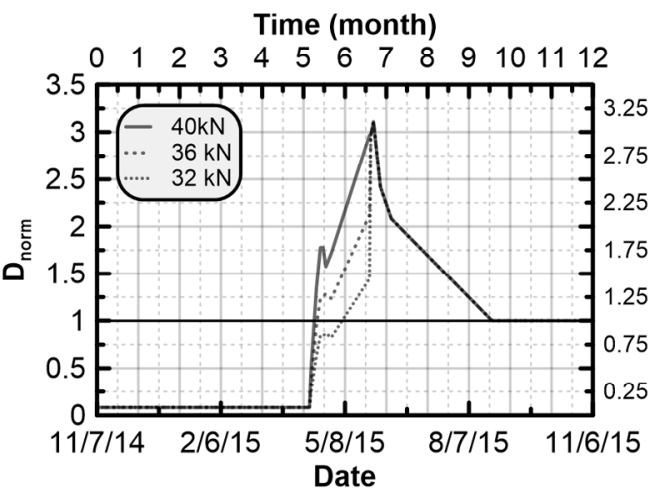

Figure 6. Calculated normalized damage in 2014 and 2015 for the 200 and $100 \mathrm{~mm}$ AC test sections

Table 5. Start and end date for SLR in 2014 and 2015

\begin{tabular}{cccc}
\hline AC thickness & Year & Start & End \\
\hline $200 \mathrm{~mm}$ & 2014 & April 15th & June 4th \\
$200 \mathrm{~mm}$ & 2015 & April 15th & June 3rd \\
$100 \mathrm{~mm}$ & 2014 & April 11th & May 30th \\
$100 \mathrm{~mm}$ & 2015 & April 13th & May 26th \\
\hline
\end{tabular}


356 Considering the area under the curve for each $D_{\text {norm }}$ as a function of time plot, it is possible to 357 calculate the total relative damage occurring throughout the yearly cycle, as presented in Table

358 6. When looking at the data presented in Table 6, it is observed that the relative damage for the 359 two experimental sections reduced by about $7 \%$ (200 mm AC, 0.82 to 0.76 in 2014$)$ to $10 \%$ (100 $360 \mathrm{~mm} \mathrm{AC,} 1.15$ to 1.03 in 2015) when the load is reduced from 40 to $32 \mathrm{kN}$ during spring time. The $361100 \mathrm{~mm}$ AC test section shows the highest relative damage values, for both 2014 and 2015 , with 362 values higher than 1 in 2015 (1.15). This means that the total damage over the yearly cycle, 363 considering a variable pavement response, is higher than if the pavement response was kept 364 constant at summer-like conditions.

Table 6. Total relative damage calculated for loads of 40, 36 and $32 \mathrm{kN}$ for the two experimental sections in 2014 and 2015

\begin{tabular}{lcccc}
\hline & & $40 \mathrm{kN}$ & $36 \mathrm{kN}$ & $32 \mathrm{kN}$ \\
\hline $200 \mathrm{~mm} \mathrm{AC}$ & 2014 & 0.82 & 0.79 & 0.76 \\
$200 \mathrm{~mm} \mathrm{AC}$ & 2015 & 0.48 & 0.47 & 0.45 \\
$100 \mathrm{~mm} \mathrm{AC}$ & 2014 & 0.93 & 0.9 & 0.86 \\
$100 \mathrm{~mm} \mathrm{AC}$ & 2015 & 1.15 & 1.08 & 1.03 \\
\hline
\end{tabular}

371 The damage analysis also allowed assessing the percentage of damage specific to each season.

372 This calculation was performed using the historical season lengths for the test site, as defined in

373 Table 7. A simplified procedure, based on the work of Drolet (2015) and Bilodeau et al. (2013)

374 that uses five seasons during the yearly cycle (summer, fall, winter, early spring and late spring),

375 was used to define the length of a season. Using a yearly temperature sinus function, the winter

376 length is defined by the number of days where the temperature is below $0{ }^{\circ} \mathrm{C}$. The length of the 
377 season combining early and late spring has been established based on temperature data

378 previously collected and was found to be 57 days for the test location considered, starting at the

379 end of the winter. The length of summer combined with fall seasons is the time between the

380 end of spring and the beginning of winter.

Table 7. Historical seasons durations at the test site

\begin{tabular}{cccc}
\hline Season & Winter & Spring & Summer and Fall \\
\hline Number of days & 153 & 57 & 155 \\
\hline
\end{tabular}

The results of this analysis are presented in Table 8 . Table 8 shows that a significant portion of 386 pavement damage occurred during summer and spring (98 to $99 \%$ of yearly total damage) for 387 the experimental pavement tested. Pavement damage during summer represents a significant 388 part of yearly fatigue cracking damage. However, considering the fact that the spring period is 389 much shorter than the summer period, the amount of damage that occurs on a daily basis 390 during spring is of greater importance. The results presented in Table 8 also emphasize the 391 effect of the pavement structural capacity, as the amount of damage during spring is closer to, if 392 not greater than (for the 2015 monitoring period), the summer damage for the $100 \mathrm{~mm} \mathrm{AC}$ 393 section. However, the spring damage for the $200 \mathrm{~mm} \mathrm{AC}$ test sectionis significantly lower than 394 the damage occurring during summer. Therefore, the $200 \mathrm{~mm}$ AC test section is less sensitive to 395 spring thaw conditions than the $100 \mathrm{~mm} \mathrm{AC}$ test section. As for the comparison of both 396 experimental sections for the spring period, the amount of seasonal damage is about $31 \%$ 397 higher (2014 and 2015) for the test section with the lowest structural capacity. 
Table 8. Seasonal damage for the two experimental sections in 2014 and 2015

\begin{tabular}{lcccc}
\hline & & \multicolumn{3}{c}{ Seasonal damage (\%) } \\
\cline { 3 - 5 } & & Winter & Spring & Summer \\
\hline $200 \mathrm{~mm} \mathrm{AC}$ & 2014 & 2 & 32 & 67 \\
$200 \mathrm{~mm} \mathrm{AC}$ & 2015 & 1 & 38 & 61 \\
$100 \mathrm{~mm} \mathrm{AC}$ & 2014 & 2 & 42 & 57 \\
$100 \mathrm{~mm} \mathrm{AC}$ & 2015 & 2 & 50 & 48 \\
\hline
\end{tabular}

401

402

403

\section{Conclusion}

Spring thaw induces challenging performance conditions to flexible pavements in cold regions.

407 Among other factors, the rapid increase of the degree of saturation in soils and pavement

408 materials due to more frequent liquid precipitations, the melting of ice and snow and the

409 melting of segregation ice exacerbated by poor drainage conditions, are all factors involved in

410 damage rate increase during the spring period. This paper summarizes the results of an

411 experimental investigation on the evolution of pavement response during spring thaw. Two test

412 sections located at the Laval University experimental road site were intensively monitored for

413 temperature and deflections using a falling weight deflectometer during 2014 and 2015. The

414 experimental test sections were built on a silty sand subgrade and had the same structure,

415 except for the asphalt concrete thicknesses, which were 100 and $200 \mathrm{~mm}$. Falling weight

416 deflectometer tests were carried through the yearly cycle, but were more intensive during the

417 spring thaw period. The main findings of this research work are the following: 
- A rapid increase of fatigue damage is observed from the beginning of spring thaw until the warmest conditions of the year;

- The decrease of the applied load results in a significant decrease of fatigue damage.The relative damage for the two experimental sections is reduced by about $7 \%$ ( $200 \mathrm{~mm}$ AC, 0.82 to 0.76 in 2014$)$ to $10 \%$ (100 mm AC, 1.15 to 1.03 in 2015) when the load is reduced from 40 to $32 \mathrm{kN}$ during spring time; The section with the lowest structural capacity shows the highest yearly damage relative to summer conditions, reaching relative damage values of 1.15;

- As expected, very little fatigue damage $(1-2 \%)$ occurs during the winter period. The fatigue damage is shared between spring and summer in a proportion of approximately $50 \%$ spring and $50 \%$ summer for the thin asphalt section and of about $33 \%$ spring $66 \%$ summer for the thick asphalt section; $\mathrm{mm}$, the fatigue cracking damage being $31 \%$ higher for the $100 \mathrm{~mm} \mathrm{AC}$ test section when compared to the $200 \mathrm{~mm}$ AC test section;

\section{Acknowledgements}


440 The research team of this project would like to thank the Quebec Ministry of Transportation for 441 their financial, technical and professional support for this project. The members would like also 442 to thank Sylvain Auger for his work with the test preparation.

443

444

445 


\section{References}

447

448 Andersland, O. B. and Ladanyi, B. 2004. An introduction to frozen ground engineering. John 449 Wiley \& sons.

450

451 Asphalt Institute 1991. Thickness design-asphalt pavements for highways and streets. Ninth 452 edition, Asphalt Institute, Manual Series No. 1 (MS-1).

454 Badiane, M. 2016. Effet des charges sur les chaussées en période de restriction des charges455 volet terrain. Master Thesis, Université Laval, Québec, Canada.

457 Badiane, M., Yi, J., Doré, G., Bilodeau, J.-P. and Prophète, F. 2015. Monitoring of flexible 458 pavement structure during freezing and thawing. In proceedings of the International Conference 459 on Cold Regions Engineering, Salt Lake City, USA, July 19th to 22th, 13p.

461 Barksdale R. D. The Aggregate Handbook. National Stone Association, Washington D.C., 1991.

463 Bilodeau, J.-P., Drolet, F. P. and Doré, G. 2015. Correction of air freezing index for pavement 464 frost protection design to consider future climate changes. Canadian Journal of Civil Engineering, $465 \quad 10.1139 /$ cjce-2015-0475. 
467 Bilodeau, J.-P., Drolet, F. P., Doré, G. and Sotile, M.-F. 2015. Effect of Climate Changes Expected

468 During Winter on Pavement Performance. In proceedings to the International Conference on

469 Cold Regions Engineering, Salt Lake City, USA, July 19th to 22th, 12p.

470

471 Bilodeau, J.-P. and Doré, G. 2012. Resilient modulus water sensitivity of compacted unbound

472 granular materials used as pavement base. International Journal of Pavement Engineering,

473 13(5): 459-471.

475 Bilodeau, J.-P. 2009. Optimisation de la granulométrie des matériaux granulaires de fondations 476 des chaussées. Ph.D. dissertation, Laval University, Québec, Canada.

478 Bullock, M. et Tighe, S. et Bolduc, P. 2006. The opportunities for intelligent transportation

479 systems to assist with spring load restrictions and winter weight premiums. Annual conference 480 of the Transportation Association of Canada, Charlottetown, Prince Edward Island. 23p.

482 C-SHRP 2000. Restrictions saisonnières de charge imposées au Canada et dans le monde.

483 Bulletin technique, n. F21, 8 p.

485 Doré, G. 1997. Détérioration des chaussées en conditions de gel : une nouvelle approche 486 prévisionnelle. PhD dissertation, Université Laval, Québec. 
488 Doré, G. 2004. Development and Validation of the Thaw-Weakening Index. International Journal 489 of Pavement Engineering, vol. 5, no. 4, http://www.informaworld.com, pp. 185-192.

Doré, G. and Zubeck, H. 2009. Cold regions pavement engineering. McGraw-Hill, NY.

493 Doré, G., and Savard, Y., 1998. Analysis of Seasonal Pavement Deterioration. Transportation

494 Research Board, preprint no. 981046, Transportation Research Board of the National

495 Academies, Washington, D.C.

497 Doucet, F. et Auger, B. 2012. Complex Modulus Determination of Asphalt Mixes at The Ministère 498 Des Transports Du Québec. Transports Québec report no. RTQ-10-01, 2010.

500 Doucet, F. et Doré, G. 2004. Module réversible et coefficient de poisson réversible des

501 matériaux granulaires C-LTPP. In Proceedings of the 57th Canadian Geotechnical and 5th Joint

502 IAH-CNC and CGS Groundwater Specialty Conferences CD-Rom, Québec, Québec.

504 Drolet, F. P. 2015. Effets des changements climatiques sur la performance à long terme des 505 chaussées souples au Québec : Volet 2-Effet de l'augmentation de la température en hiver et 506 d'une hausse du nombre d'épisode de redoux hivernaux. Master thesis, Université Laval, 507 Québec, Canada. 
509 Ekblad, J. 2007. Influence of Water on Coarse Granular Road Material Properties. PhD

510 Dissertation, Royal Institute of Technology, Stockholm, Sweden.

511

512 Isotalo, J. 1998. Spring load restrictions in Finland: Current policy and research implications.

513 Transportation Research Record: Journal of the Transportation Research Board, (1615), 29-31.

515 Janoo, V., and Shoop, S. 2004. Influence of spring thaw on pavement rutting. UNBAR6

516 Pavements Unbound, Nottingham, U.K., 115-124.

517

518 Konrad, J.-M. and Roy, M. 2000. Flexible pavements in cold regions: a geotechnical perspective.

519 Canadian Geotechnical Journal, 37: 689-699.

520

521 Lekarp F., Isacsson U. and Dawson A. 2000a. State on the Art. I: Resilient Response of Unbound

522 Aggregates. Journal of Transportation Engineering, 126(1): 66-75.

523

524 Lekarp F., Isacsson U. and Dawson A. 2000b. State on the Art. II: Permanent strain Response of 525 Unbound Aggregates. Journal of Transportation Engineering, 126(1): 76-84. 
527 MacLeod, D., Palsat, D., Clayton, A. 2002. Rationalization and Harmonization of Spring Weight

528 Restrictions and Winter Premiums for Roads in the Prairie Region of Western Canada. Pavement

529 Session of the 2002 Annual Conference of the Transportation Association of Canada, Winnipeg,

530 Manitoba.

531

532 Nixon, J., and Morgenstern, N. R. 1971. One Dimensional Consolidation of Thawing Soils,

533 Canadian Geotechnical Journal, vol. 8, no. 4, pp. 558-565.

534

535 Ovik, J. M., D. A. Van Deusen, and J. A. Siekmeier, 2000. Improved Spring Load Restriction

536 Guidelines Using Mechanistic Analysis. Report MN-RC-2000-18. Minnesota Department of

537 Transportation, $90 \mathrm{p}$.

538

539 Refsdal, G., Senstad, P., and Soerlie, A. 2004. Lifting All Seasonal Load-Restrictions in Norway in

5401995 Background and Effects. Transportation Research Record: Journal of the Transportation

541 Research Board, (1874), 174-180.

542

543 Richter, C.A. 2006. Seasonal variations in the moduli of unbound pavement layers. Federal

544 Highway Administration, report FHWA-HRT-04-079, 283 p.

545

546 Saarenketo, T. and Aho, S. 2005. Managing spring thaw weakening on low volume roads. Report

547 on Task 2.3. Roadex II Project., $130 \mathrm{p}$. 
549 Saevarsdottir, T. and Erlingsson S. 2013. Water impact on the behaviour of flexible pavement

550 structures in an accelerated test. Road Materials and Pavement Design 14(2): 256-277.

551

552 Saint-Laurent, D. 2003. Impact des restrictions de charges en période de dégel. INFO-DLC, Vol. 8, $553 \quad n^{\circ} 11,2 p$.

555 Salour F, Erlingsson S. 2013. Moisture sensitive and stress dependent behavior of pavement 556 unbound materials from In situ falling weight deflectometer tests. Transportation Research 557 Record: Journal of the Transportation Research Board 2335: 121-129.

559 Salour, F. 2015. Moisture Influence on Structural Behaviour of Pavements. Doctoral Thesis, 560 School of Architecture and the Built Environment, Royal Institute of Technology, Stockholm, 561 Sweden.

563 Salour, F. et Erlingsson, S. 2013. Investigation of a pavement structural behaviour during spring 564 thaw using falling weight deflectometer. Road Materials and Pavement Design, 14:1, 141-158.

566 Suarez, C. A. M., Doré, G. and Bilodeau, J.-P. 2010. Resilient modulus estimation for granular 567 materials. In Proceedings of the 11th International Conference on Asphalt Pavements CD-ROM, 568 Nagoya, Japan, August 1st to 6th, 9 p. 
570 Tammirinne, M., Valkeisenmäki, A. and Ehrola, E. 2002. Road structures research program 1994-

571 2001. Summary report, Finnra Reports 37/2002, Finnish Road Administration, Helsinki, Finland.

572

573 Theyse H. L. 2002. Stiffness, strength and performance of unbound aggregate material:

574 Application of South African HVS and laboratory results to California flexible pavements. Report

575 for the California Pavement Research Program 2002, University of California, Pavement

576 Research Center.

577

578 Thom N. H. and Brown S. F. 1987. The effect of moisture on the structural performance of a

579 crushed-limestone road base. Transportation Research Record, 1121: 50-56.

581 Transportation Association of Canada 1997. Pavement design and management guide. Dr. Ralph

582 Haas Ed., Waterloo, ON.

584 Uthus, L. 2007. Deformation properties of unbound granular materials. PhD Dissertation,

585 University of Trondheim, Trondheim, Norway.

587 White, T.D. and Coree, B.J. 1990. Threshold pavement thickness to survive spring thaw.

588 Proceedings of the 3rd International Conference on Bearing Capacity to survive Spring Thaw.

589 Throndheim, Norway. 
https://mc06.manuscriptcentral.com/cjce-pubs 